\title{
Correlation Between an Exclusive Breast Feeding with Baby's Nutritional Status Assessed at Primary Health Care, Region I in North Denpasar
}

\author{
Pande Putu Novi Ekajayanti ${ }^{1}$, Pande Putu Indah Purnamayanthi ${ }^{1}$ \\ ${ }^{1}$ Midwifery Study Program, STIKES Bina Usada Bali \\ Email: novee_cutz@yahoo.com
}

Received 1 February 2019; Accepted 1 February 2019; Published 22 May 2019

\begin{abstract}
According to data from the Basic Health Research of Indonesia (Riskesdas), exclusively breastfed babies has reached only $15.3 \%$ in 2010 . While in Denpasar, its level fell from $62.2 \%$ in 2007 to $56.2 \%$ in 2008 for infants aged 0-6 months. This study aims to find out an exclusive breastfeeding given in infants, assessing infant's nutritional status, and the correlation between an exclusive breastfeeding with infant's nutritional status at Primary Health Care, Region I in North Denpasar. This research used a observation analytic method. Subjects were given exclusively breastfed for totally 45 respondents. This type of sampling using a purposive sampling. Statistical analysis was done by Chi-Square. Respondents were breastfed exclusively has higher normal nutritional status for about $51.1 \%$ compared with those whose was not given, showing only $15.6 \%$. Statistical test results employed the Chi-Square method with a p-value of 0.005 and $\alpha 0.05$, which means $\alpha$ p-value less than $\alpha$. This result suggests that there is a correlation between exclusively breastfeeding with infant's nutritional status.
\end{abstract}

Keywords: Exclusive Breast Feeding, Nutrition Status, Baby

Copyright $\odot 2019$ STIKes Surya Mitra Husada

All right reserved.

This is an open-acces article distributed under the terms of the Creative Commons AttributionShareAlike 4.0 International License.

\section{INTRODUCTION}

Babies need nutrients in order to grow and develop appropriately. The nutrition needs are much less than adults, but it comes to the greater amount when compared to per unit of body weight. Nutritious food is the main requirement for the baby in order to gain the optimum growth and development processes, hence the comprehensiveness in the nutrition elements should be prioritized in the daily baby's diet (Sulistyoningsih, 2013).

Nutritional status is one of the factors found at the individual level (the most micro level). The direct factors influence namely food intake and infection. One source of good nutrition for babies is an exclusive breastfeeding as it comes as a balanced nutritional value and contains a variety of nutrients which are very important to meet baby's needs. There are three indirect effects of nutritional status namely food security in the family, child nurturing pattern and healthy environment, as well as an appropriate health access (Riyadi, 2001 cited by Simarmata, 2012).

The nutritional status in infants can be assessed from their growth process. A healthy baby who has been fulfilled his nutritional needs will achieve appropriate according to his age (Sulistyoningsih, 2013). Based on the growth curve published by the National Center for Health 
Statistics (NCHS), the weight of babies who are exclusively breastfed increases more slowly than babies who get formula milk (MP-ASI). This does not mean that greater weight in infants who get formula milk is better than babies who get breastfeeding. An excessive body weight of babies who get formula milk actually indicates the occurrence of obesity. It is important to provide breastfeeding for babies at least until they reach two years old of age. For the babies who get breastfeeding gain a good increasing of body weight increase, growth, and reduce the possibility of obesity (Kristiyanasari, 2014). The baby's growth will be monitored by doing anthropometric measurements then assessing nutritional status by matching the age of the child (in months) with the standard body weight of the World Health Organization-National Center for Health Statistics WHO-NCHS table (Proverawati and Asfuah, 2012).

Breast milk is the best food for babies, especially in the beginning of their lives because its composition is perfectly met by the baby's physiological conditions during the first days of birth. They still have a sensitive and vulnerable alimentary tract system hence, only breast milk can be digested and absorbed by their intestine (Sulistyoningsih, 2013).

The baby's need for nutrients is very high whom can be fulfilled by giving breast milk only. Breastfeeding is more beneficial than formula milk or what is known as Breast Milk Substitute (PASI), as it provides many benefits for babies. Babies who get exclusive breastfeeding will gain all the advantages of ASI and fulfill their nutritional needs optimally so that they will be healthier. As a result, babies who get breast milk exclusively will experience optimal growth milestone (Sulistyoningsih, 2013).

In the health national development program, the improvement of human resources quality must be begun as early as possible, since an early age of the infant and one of the pivotal method is by providing the breastfeeding program. The optimal breastfeeding program may be an important role to nurture and preparing future generations. It is being concerned recently about an increasing provision of ASI. Political government supports for exclusive breastfeeding has been sufficiently enough, as the launching of the National Movement to Increase the Use of Mother's Milk (GNPPASI) by President General Soeharto in Mother's Day on December 22nd, 1990 ago titled "With Breastfeeding, Mother's role as a pioneer of an Indonesian human quality's improvement ". In his speech, Mr. president also stated that breastfeeding as a main nutrition intake and should be given until the baby reaches six old months of age. The term breastfeeding without giving any other foods supplement is known as an exclusive breastfeeding. Furthermore, the baby needs to get complimentary food for ASI, then breastfeeding is continued until the child reached two years old of age (Depkes RI, 2015).

However, there are some concerns that many mothers may not want to breastfeed exclusively due to less enough nutrition factor from mother point of view. Other than that, the facts that a mother may also be a working mother and having an insecure feeling that breastfeeding is inadequate, and also the obstacles of family members and surrounding communities. An exclusive breastfeeding accelerates reducing of an infant mortality and at the same time improving the nutritional status of toddlers which in turn will improve the nutritional status of the community towards the achievement of adequate quality human resources (Depkes RI, 2015). According to the Basic Health Research Data (Riskesdas) shows the coverage of exclusive breastfeeding in Indonesia from 2002 to 2003 was $14 \%$ and for infants aged up to six months in Indonesia also fell from $28.6 \%$ in the year 2007 to $24.3 \%$ in 2008, and 18\% and $15.3 \%$ in 2012 and 2010, consecutively. Whereas in Denpasar the coverage of exclusive breastfeeding in infants from $0-6$ month of age fell from $62.2 \%$ to $56.2 \%$ in period 2007 to 2008.

According to the previous result study which conducted at same Primary Health Center, it revealed out of 5 babies aged 6-12 months old there were $20 \%$ of them have over nutritional status, $60 \%$ have an optimum nutritional status, and rest of them belong to under-nutrition status. Whereas 5 babies without exclusive breastfeeding recorded about $60 \%$ of over nutritional status, $20 \%$ have an optimum nutritional status, and the rest of them belong to under-nutritional status. These data recorded using anthropometric measurement techniques and assessment of nutritional status per body weight for age (BB / U) according to gender. This data was gained from a simple survey of 15 infants examined at Primary Health Center, Region I in North Denpasar. From this description, the writer is interested in researching "Correlation between an Exclusive Breast Feeding with Baby's Nutritional 
Status". This research is aims to determine the correlation between an exclusive breastfeeding with baby's nutritional status assessed at Primary Health Center, Region I, North Denpasar.

\section{MATERIALS AND METHODS}

A observation analytic research method is employed in order to find out the correlation between two variables in the study (Sugiyono, 2001 in Hidayat 2012). A cross-sectional approach (cross-sectional surgery) was as an approach for observational or collecting data at a point time approach (Notoatmodjo, 2012). This study aims to determine the correlation between an exclusive breastfeeding with baby's nutritional status.

The sampling technique used was non-probability sampling, which everyone in the population has the unequal opportunity to become a sample. The purposive sampling has been chosen based on the researcher's considerations or criteria (Fajar, 2012). The inclusion criteria are as follows: Babies aged 6-12 months; Babies aged 6-12 months who were given exclusive breastfeeding without any complemented with MP-ASI Babies aged 6-12 months who has been given MP-ASI. The mother who was willing to make her baby being as a respondent. The exclusion criteria are as follows: Babies who didn't want to suckle; A mother who was not willing to make a baby as a respondent

This research was conducted at North Denpasar Health Center I in April - May 2017. The research data collection method is as follows: The researchers ask for informed consent to conduct that study Primary Health Center, Region I, North Denpasar. After the consent was approved, the researcher explained the aims, purpose, and benefits of the study. After understanding the purpose of the study, respondents were asked to sign an informed consent to be a respondent. The researcher gave a questionnaire about exclusive breastfeeding with the category "Yes and No". The researchers conducted anthropometric measurements of all respondents who visited the Primary Health Center, Region I, North Denpasar to assess their nutritional status and categorized as "normal and abnormal nutrition"

\section{RESULTS}

\section{Univariate Analysis}

a. Exclusive breastfeeding

Table 1 Distribution of Frequency of Respondents Based on Exclusive Breastfeeding at North Denpasar Health Center I in 2017

\begin{tabular}{ccc}
\hline \multirow{2}{*}{ Giving ASI Exclusive } & Frequency (F) & Percentage (\%) \\
\hline Yes & 28 & 62,2 \\
\hline Not & 17 & 37,8 \\
\hline Total & 45 & 100 \\
\hline
\end{tabular}

From table 1: Frequency distribution of respondents based on an exclusive breastfeeding at Primary Health Center, region I, North Denpasar, it shows that from 45 total respondents, babies who were exclusively breastfed were 28 people $(62.2 \%)$ and babies who were not exclusively breastfed 17 people (37.8\%). 


\section{b. Nutritional Status of Respondents}

Table 2 Distribution of Frequency of Respondents Based on Respondent Nutritional Status at North Denpasar Health Center I in 2017

\begin{tabular}{ccc}
\hline Responden Nutritional Status & Frequency $(\mathbf{F})$ & Percentage (\%) \\
\hline Normal & 30 & 66,7 \\
\hline Abnormal & 15 & 33,3 \\
\hline Total & 45 & 100 \\
\hline
\end{tabular}

From table 2: frequency distribution of respondents based on infant nutritional status at Primary Health Center, region I, North Denpasar, shows that from 45 total respondents who had normal nutritional status were 30 people $(66.7 \%)$ and those with abnormal nutritional status were 15 people (33.3\%).

\section{Bivariate Analysis}

Table 3. Correlation between an exclusive breastfeeding with baby's nutritional status at Primary Health Care, Region I, North Denpasar

\begin{tabular}{cccccccc}
\hline \multirow{2}{*}{ Giving ASI Exclusive } & \multicolumn{3}{c}{ Baby Nutritional Status } & \multicolumn{3}{c}{ Total } \\
\cline { 2 - 6 } & \multicolumn{2}{c}{ Normal } & \multicolumn{2}{c}{ Abormal } & \multicolumn{2}{c}{ F } & \% \\
\cline { 2 - 6 } Yes & 23 & 51,1 & 5 & 11,1 & 28 & 62,2 \\
\hline Not & 7 & 15,6 & 10 & 22.2 & 17 & 37,8 \\
\hline Total & 30 & 66,7 & 15 & 33,3 & 45 & 100 \\
\hline
\end{tabular}

From table 3: The correlation between an exclusive breastfeeding with baby's nutritional status at Primary Health Center, Region I, North Denpasar shows the proportion of respondents who were exclusively breastfed has had a higher normal nutritional status about $51.1 \%$ compared to the proportion of respondents who were not exclusively breastfed with a normal nutritional status was counted only 15, 6\%. The statistical data using Chi-square obtained a p-value of 0.005 and $\alpha 0.05$, which means that p-value is smaller than $\alpha$, hence indicating that there is a correlation between an exclusive breastfeeding with baby's nutritional status at Primary Health Center, Region I, North Denpasar.

\section{DISCUSSION}

The baby's need for nutrients is very high whom can be fulfilled by giving breast milk only. Breastfeeding is more beneficial than formula milk or what is known as Breast Milk Substitute (MPASI), as it provides many benefits for babies. Babies who get exclusive breastfeeding will gain all the advantages of ASI and fulfill their nutritional needs optimally so that they will be healthier. As a result, babies who get breast milk exclusively will experience an normal growth milestone (Sulistyoningsih, 2013).

Nutritional status is one of the factors found at the individual level (the most micro level). The direct factors influence namely food intake and infection. One source of good nutrition for babies is an exclusive breastfeeding as it comes as a balanced nutritional value and contains a variety of nutrients which are very important to meet baby's needs. There are three indirect effects of nutritional status namely food security in the family, child nurturing pattern and healthy environment, as well as an appropriate health access (Riyadi, 2001 cited by Simarmata, 2012). 
Univariate analysis revealed from 45 total respondents, the baby who received an exclusively breastfeeding were $28(62.2 \%)$ compared to $17(37.8 \%)$ who were not given. The reasons varied, either due to working mother's status or non-produced breast milk any longer. The results of a univariate analysis in nutritional status of the respondents found from 45 total respondents, 30 babies (66.7\%) have an normal nutritional status, whereas 15 babies (33.3\%) have an abnormal nutritional status. The reasons were varied, either due to poor socio-economic status or baby's illness.

The results of the bivariate analysis aimed to determine the correlation between an exclusive breastfeeding with the nutritional status of infants have found a positive correlation. Those infants who were exclusively breastfed have a higher normal nutritional status compared to infants who were not given, counted $51.1 \%$ and $15,6 \%$, consecutively. The reasons were the nutrient content of breast milk has met the baby's needs, so that it has a positive impact on their nutritional status.

According to the author, babies who get an exclusive breastfeeding would experience an appropriate weight gain after birth, good growth milestone, and reducing the possibility of an obesity. According to Kristiyanasari (2012), the exclusive breastfeeding with give some advantages to the babies and fulfill their nutritional needs to the fullest, so that they will be healthier. As a result, babies who are exclusively breastfed will experience an optimal growth milestone which affects the nutritional status and eventually have an normal nutritional status.

From the cross table data, it revealed the tendency of infants who were exclusively breastfed to have a normal nutritional status, confirmed by the Chi-square value was 7.988 sig 0.005 , furthermore, the hypothesis tested with the value of $\alpha=0.05$. With a sig value of $0.005<0.05$, it can be seen that $\mathrm{Ho}$ is rejected and $\mathrm{Ha}$ is accepted, which means that there was the positive correlation between exclusive breastfeeding with baby's nutritional status. It is in accordance with Kristiyanasari's opinion (2012) that an exclusive breastfeeding will increase better weight gain after birth, good growth milestone, and reducing the possibility of obesity.

\section{CONCLUSION}

Based on the results, it can be concluded that: from 45 total of respondents, babies who were exclusively breastfed were 28 people (62.2\%) at Primary Health Centre, Region I, North Denpasar. Those infants who were exclusively breastfed have a higher normal nutritional status compared to infants who were not given, counted $51.1 \%$ and 15, 6\%, consecutively. Most babies given exclusive breastfeeding have normal nutritional status. There is a significant correlation between an exclusive breastfeeding with baby's nutritional status at Primary Health Center, Region I, in North Denpasar. An exclusive breastfeeding can increase the baby's weight so that the nutritional status of the baby optimally gained.

From the conclusions of the research above, some suggestions can be put forward for the babies/society: it is expected to pay attention to baby food intake at home or outside setting, in order to achieve a good nutritional status. For the place of research took a place: those health workers are expected to be able continuing that good effort and further increasing an attention for infant food intake in order to achieve a normal nutritional status. For the researchers: It is expected to further improve the ability to solve the problem of infant nutritional status in order to achieve good and optimal nutritional status. 


\section{REFERENCE}

Depkes RI. (2015). Dikutip dari Siregar 2011. Pemberian ASI Eksklusif dan Faktor- Faktor Yang Mempengaruhinya. Retrivied 22 Desember 2016, availablefrom: http://library.usu.ac.id/download/fkm/fkmarifin4.pdf.

Depkes RI. (2015). Dikutip dari Savata. 2011. ASI Eksklusif susu yang sempurna. 20 Desember 2016, available from http://www.neosavata.com/wp-content/uploads/2011/09/Asi-eksklusif1.jpeg.

Fajar. (2012). Statistika Untuk Praktisi Kesehatan. Yogyakarta: Graha Ilmu.

Kristiyanasari. (2012). ASI, Menyusui, SADARI. Yogyakarta: Nuha Medika.

Notoatmodjo. (2012). Dikutip dari Saryono, A. S. 2010. Metodelogi Penelitian Kebidanan DIII, DIV, SI dan S2. Yogyakarta: Nuha Medika.

Simamarta. (2012). Dikutip dari Lusa 2012. Gizi Seimbang Bagi bayi. Retrivied 20 Desember 2016, availablefrom: http://www.lusa.web.id/gizi-seimbang-bagi-bayi/.

Sulistyoningsih. (2013). Gizi Untuk Kesehatan Ibu dan Anak. Yogyakarta: Graha Ilmu. 